\title{
What Common Yugoslav Culture Was and How Everybody Benefited From It
}

\author{
By Zoran Milutinović, University College, London
}

\section{ABSTRACT}

This chapter's main thesis is that Yugoslavia was not merely an agglomeration of constituent national cultures, but that during its seventy-year long existence it managed to create a supranational, common cultural layer in which all Yugoslavs took part. The author explains what constituted that common culture, how all Yugoslav benefited from it, and what appeared in its stead after the dissolution of Yugoslavia.

Most of what has been written during the last two decades about the seventy-year long period of Yugoslavia's existence has been decisively colored by the final act of its dissolution. What is more, many recent studies on Yugoslavia, with some notable exceptions, have been written from either nationalist or anti-communist perspectives, providing ample evidence for the views of those who were, both inside and outside the country, its enemies, in whatever shape and form the country was constituted. From either of these two perspectives it is very difficult, if not altogether impossible, to say anything positive about Yugoslavia. Yet, quite beyond nostalgia and sentimentality, which should not be allowed to guide academic inquiry, the historical account of this country must be supplemented by views which explain how Yugoslavs managed to remain together for as long as they did, and how the existence of this state was not entirely 
detrimental to their national and individual interests. Surely they didn't spend every minute of their days suffering under communist oppression and engaged in nationalist quarrels, kept together only by Marshal Tito's iron fist? Wasn't there more to life in Yugoslavia?

My main thesis is that Yugoslavia was not merely an agglomeration of constituent national cultures, but that during its seventy-year long existence it managed to create a supranational, common cultural layer in which all Yugoslavs took part. I shall try to explain what I think constituted that common culture, how all Yugoslavs benefited from it, and what appeared in its stead after the dissolution of Yugoslavia.

Calling ex-Yugoslav cultures "small" should neither offend nor surprise anyone. The smallness of small cultures is not merely a matter of small numbers - although strength in numbers certainly influences cultural production to a significant extent— but also refers to what Pascale Casanova aptly expressed with the phrase "cultures poor in resources." Despite all efforts to extend equal recognition to all cultures, the international cultural space is not a sphere of respectful mutual recognition, harmony, and justice, but, as Casanova pointed out, one of inequality between the centre and periphery, of struggle for supremacy, of domination, hierarchy, competition, and resistance. Under such circumstances all cultures poor in resources are driven by two contradictory aims: they try to resist domination by the richer and stronger, which pushes them towards isolationism, and they struggle for recognition in the wider cultural arena, which encourages them to open up. Pursuing these aims, all resource-poor cultures have three main imperatives:

\footnotetext{
${ }^{1}$ Pascale Casanova, The World Republic of Letters (Cambridge, MA: Harvard University
} Press, 2004). 
1. To root themselves in other cultural traditions, in order to appropriate their cultural resources and transform them into their own patrimony, into their own cultural capital, which eases the accumulation of resources;

2. To find a place for themselves within a broader paradigm in which they can encounter other cultures, whether in dialogue or competition; without that sort of interaction, cultures are sentenced to provincialism, stagnation, and eventual disappearance, and those poor in resources even more so;

3. To find a wider audience for their resources, which again, as is the case with the two previous imperatives, leads them outside of themselves.

While striving to accomplish these three imperatives - acquisition of patrimony, entering a broader paradigm, and widening one's audience — cultures poor in resources need to be wary of the following two liabilities:

1. They need to choose carefully which foreign patrimony they appropriate and transform into their own resources. While appropriating a foreign patrimony as one's own always entails some form of cultural dependency, an overlap of political supremacy and cultural dependency is ultimately fatal for resource-poor cultures.

That is part of the reason why Polish and Romanian culture opted for rooting themselves in French, as opposed to German or Russian patrimony.

2. The second potential liability is that resource-poor cultures enter a broader paradigm which surpasses their strength to such an extent that neither dialogue nor competition seems possible. If they make such a fatal choice, they are bound to lose their confidence, at the very least, if not to suffocate and disappear altogether. 
For Yugoslav peoples and the most numerous ethnic minority - the Albanians - common Yugoslav culture was a broader paradigm in which all three imperatives were realized, and both liabilities avoided.

By "common Yugoslav culture" I am not referring to any of the three grand projects of Yugoslav cultural policy — the romantic, the synthetic, or the multicultural—because as Andrew Wachtel has demonstrated, the romantic was never seriously contemplated, and the latter two were not entirely successful. ${ }^{2}$ However, both common Yugoslav culture and the three grand projects were rooted in the same series of events that inaugurated cultural cooperation among the South Slavs. This cooperation began to take shape at the beginning of the nineteenth century, and was contemporary with and to a great extent intertwined with the birth of the individual modern South Slav cultures. The story is all too familiar: Bartholomius Jernej Kopitar, a Slovene, convinced Vuk Karadžić, a Serb, to begin a battle for a standard language reform and to collect examples of oral literature which would serve as the patrimony of the new literary culture in the making, which in turn inspired Ljudevit Gaj, a Croat, to initiate a broad movement in Croatia, Dalmatia, Slavonia, Bosnia and Herzegovina, with the aim of creating a common "Illyrian" or South Slav culture. This cooperation had its ups and downs, and was not the only route to the modernity of Serbian, Croatian, and Slovene cultures; nor was it the only current within them. However, the stimuli it provided, and the results it brought about, must not be underestimated: from Serbian actors from Novi Sad traveling to Zagreb to show the public that theater in one's own language is possible, to the Croat Josif Pančić becoming the first president of the Serbian

${ }^{2}$ Andrew B. Wachtel, Making a Nation, Breaking a Nation: Literature and Cultural Politics in Yugoslavia (Stanford, CA: Stanford University Press, 1998). 
Royal Academy, to the many examples from the first decade of the twentienth century which show that many "Illyrians" felt at home everywhere between Austria and Bulgaria, and treated it as a single cultural space.

However, neither spontaneous cultural cooperation nor the post-1918 attempts to synthesize South Slav cultures bore any lasting results, because the synthesis was always conceived as an almost mechanical fusion between whole cultures. It is not difficult to reproach the early Yugoslav cultural enthusiasts for their naïveté and to criticize their unfounded, utopian projections of a coming Yugoslav culture. Nevertheless, a century later we too are at a loss when pressed to answer the same simple question: how do cultures grow together, and what does this "togetherness" mean exactly? Historical evidence teaches us only about cultures growing apart: we can accurately trace the disintegration of Medieval Latin culture into vernacular protonational ones, but historians still cannot put forward an example which can be analyzed, described, and offered as a model for the process of cultures growing together. Here, we can only wonder, hope, and attempt wild utopian projections - as we actually do whenever we want to talk about the synthesized European culture yet to come. Yugoslav culture enthusiasts in the 1920s were faced with the same problem. They proposed a number of utopian paths to be taken, and in their proclamations they forged metaphors and competed in lyrical creativity, but ultimately they were no wiser than anyone wondering today how to integrate different national cultures into a European one.

Whenever individual Yugoslav cultures attempted to cooperate as distinct units through their individual representatives, it ended in failure, be it the Novi Sad Agreement, the common core curriculum which never materialized in the intended form, or, quite symbolically, the writing of the history of Yugoslav literatures, planned to be the eighth volume of The History of 
World Literature published by Liber and Mladost in Zagreb in the 1970s. ${ }^{3}$ However, throughout the nineteenth and especially in the twentieth century, there were two distinct cultural layers in the territory formerly known as Yugoslavia: a national and a supra-national one. Neither the Ottoman nor the Habsburg state - despite their long rules — succeeded in creating a vibrant supra-national cultural layer in the lands of the South Slavs. By contrast, Yugoslavia managed to create such a supra-national layer over the course of its seventy-year existence, despite the relative failure of its cultural policy. The analogy with Goethe's notion of world literature - $\mathrm{a}$ literature which transgresses national borders and becomes the patrimony of other nations — only imperfectly explains what I here term as common culture. ${ }^{4}$ It does not merely designate a book by a Macedonian author read in Bosnia, but a whole cultural production, which ignored the existence of national, republican, and linguistic borders and constituted an international cultural space. It was created independently of any party or state cultural policies, and sometimes in spite of them, thanks to the fact that its creators did not appear as representatives of their respective nations or republics, but as individuals. Its golden era began in the $1960 \mathrm{~s}$, at exactly the moment when the state ceased worrying about creating a unified Yugoslav culture.

\footnotetext{
${ }^{3}$ On the core curriculum see Wachtel, Making a Nation, 184-89; on the same issue, but from the perspective of Slovene nationalism, see Leopoldina Plut-Pregelj, "Slovenia's Concerns About the Proposed Yugoslav Core Curriculum in the 1980s," in The Repluralization of Slovenia in the 1980s: New Revelations from Archival Records (Seattle: The Henry M. Jackson School of International Studies, University of Washington, 2000), 58-78.

${ }^{4}$ On Goethe's concept of Weltliteratur see Fritz Strich, Goethe und die Weltliteratur (Bern: Francke, 1957 [1946]).
} 
The first significant take-off of Yugoslav cinema is associated with the genre of the "partisan film." The lists of credits in Veljko Bulajić's war epics show that these films cannot be assigned to any of the Yugoslav component cultures, and must remain the patrimony of all of them. Among the non-linguistic art forms, the best example is the Mediala group: the individual artists who belonged to it represented no one but themselves. ${ }^{5}$ Their ethnic background was quite diverse; although individual artists could be assigned to their respective national cultures, the aesthetic ideology of the group remained in shared ownership. The most striking example in the theater was Ljubiša Ristić's KPGT troupe (an acronym composed of the first letters of the four words for theater in Serbo-Croatian, Slovene, and Macedonian: kazalište, pozorište, gledališče, teatar), which brought together a number of actors, writers, directors, and set designers in a selfconsciously supra-national artistic ideology, and remained emblematic of the common culture of the Yugoslavs. ${ }^{6}$ Other significant examples also come to mind, such as the performance of Slobodan Šnajder's Croatian Faust in Belgrade's Yugoslav Dramatic Theater in the early 1980s, which joined together a Croatian playwright, a Macedonian director, a Slovene set designer, and Serbian actors. Theater directors worked nationwide. Theater festivals, such as the Dubrovnik Summer Festival, the Sarajevo Festival of Small Experimental Theaters, and the Sterijino pozorje festival in Novi Sad, were also supra-national venues; together with other festivals, such as the Pula Film Festival and Struga Poetry Evenings, they constituted the main institutional frameworks in which the common culture blossomed.

${ }^{5}$ On Mediala see Miodrag B. Protić, Srpsko slikarstvo XX veka (Belgrade: Nolit, 1970), 52536.

${ }^{6} \mathrm{KPGT}$ still awaits its historians; there is a brief outline in Petar Marjanović: Mala istorija srpskog pozorišta. XIII-XXI vek (Novi Sad: Pozorišni muzej Vojvodine, 2005), 489-90. 
The theater seemed to be the sphere which most easily lent itself to commonality, second only to popular culture, which was truly Yugoslav everywhere: the whole country listened to Bijelo dugme, Leb i sol, Yu grupa, and Buldožer; Fahreta Jahić, or Lepa Brena, was universally popular; Zana Nimani, Djordje Balašević, Josipa Lisac, and Zdravko Čolić also. ${ }^{7}$ The whole country laughed with Miodrag Petrović Čkalja, and with the stand-up comedian Nela Eržišnik from Banja Luka in Bosnia, who impersonated a woman from Zagorje in Croatia. The weeklies Start from Zagreb and NIN from Belgrade - the latter being printed in both Cyrillic and Latin script - were read everywhere, and published the works of authors from all parts of the country. The most significant intellectual project in post-war Yugoslavia, the Praxis journal and the Korčula Summer School, which was related to it, was also part of that common culture. ${ }^{8}$ The scholars who took part in it were united by the pursuit of the same intellectual goal, and did not represent their respective national cultures. Even literature, the most linguistic of arts, allowed and supported this common culture - and not only writers who simultaneously belonged to more than one national culture (such as Ivo Andrić and Vladan Desnica) but also many others who bore witness to the fact that the whole Serbo-Croatian language area functioned as one common literary culture. Krleža's "Ljubljana speech" was an event in each and every national literature,

\footnotetext{
${ }^{7}$ The best overview of Yugoslav popular music is Petar Janjatović, Ilustrovana YU Rock enciklopedija 1960-2000 (Novi Sad, 2001).

${ }^{8}$ On Praxis see Gerson S. Sher, Praxis: Marxist Criticism and Dissent in Socialist Yugoslavia (Bloomington: Indiana University Press, 1977); and M. Marković and G. Petrović, eds., Praxis: Yugoslav Essays in the Philosophy and Methodology of the Social Sciences (Dordrecht, Holland: D. Reidel, 1979). On Praxis and nationalism see William L. McBride, From Yugoslav Praxis to Global Pathos (Lanham, MD: Rowman \& Littlefield, 2001), 19-30.
} 
and had a similar effect everywhere. ${ }^{9}$ In Jovan Deretić's History of Serbian Literature, Krleža is mentioned as often as Isidora Sekulić, and more often than some canonical Serbian authors, such as Momčilo Nastasijević or Branislav Nušić. ${ }^{10}$ Even those who in the 1980s and 1990s became ardent nationalists took part in this common literary culture: the first edition of Ranko Marinković's novel Kiklop appeared in Belgrade, in Ijekavian and printed in Cyrillic; popular Bosnian Serb author Momo Kapor published all his pre-1991 books in Zagreb, in Ekavian and in Latin letters; Dobrica Ćosić published his book Stvarno i moguće in Rijeka, Croatia in 1982. One-fifth of the Yugoslav population did not share the same native language of the Serbo-Croat speaking majority, yet was included in this common literary culture through strong and extensive programs of translation, which were only a part of wider institutional arrangements for representation and recognition. The state supported these programs, without enforcing them, and there is not a single example of a Slovene, Macedonian, or Albanian writer being dissatisfied with the opportunity to address a wider audience via translation backed by state funding. For most of them, these were the first translations into any other language, and served as a springboard for translations into other, more widely taught and read languages.

Do all these examples indicate that socialist Yugoslavia managed to synthesize or unite all national cultures into a single one? Certainly not. The national cultures remained where they were, sheltered by complex legislation and protected by funding from the constituent republics. However, a number of individuals stepped out of them and created this supra-national cultural layer, which can be rightfully called Yugoslav. That patrimony cannot be easily nationalized: most of it will have to remain a common patrimony. This common cultural layer satisfied all

\footnotetext{
${ }^{9}$ Miroslav Krleža, Govor na Kongresu književnika u Ljubljani (Zagreb: Zora, 1952).

${ }^{10}$ Jovan Deretić, Istorija srpske književnosti (Belgrade: Nolit, 1983).
} 
three of the previously mentioned imperatives of resource-poor cultures. In addition to helping artists avoid the political pressure of their respective republican administrations by publishing, exhibiting, or directing "abroad" in other Yugoslav republics, which has already been commented on in the literature, it supplied what resource-poor cultures need more than talent: strength in numbers. It formed the broader cultural context in which individuals could find an opportunity for dialogue and competition, without ever running the risk of being dominated and suffocated. The latter was due not only to their relative equality (in numbers, resources, etc.), and the institutional arrangements for representation and recognition, based on the assumption that one should know about the other cultures of one's own country, but also to the fact that the national cultural layer was heavily protected from any outside interference. This common culture was strictly voluntary; one could contribute to it or take something from it at will, but no one was forced to participate in it. It also satisfied the first imperative of all cultures poor in resources - to root themselves in other cultural traditions, in order to appropriate their cultural resources and transform them into their own patrimony, into their own cultural capital—although in a manner not envisaged by the creators of Yugoslav cultural policies. The institutional arrangements of representation and recognition failed to ensure, for example, that Macedonian writer Kočo Racin (1908-1943), whose poetry was included in school textbooks all over Yugoslavia, and learnt by heart in the original Macedonian by pupils, would become the cultural patrimony of, say, Serbs and Croats; although those former pupils may still remember the lines of Racin's poem "Tutunoberachite" (“The Tobaccogatherers"), Racin remained of significance only for Macedonian culture, pretty much as the works of Prešern or Njegoš became known in other Yugoslav cultures, but remained truly productive - as elements of cultural patrimony must beonly within Slovene and Serbian or Montenegrin culture. Racin, Prešern, and Njegoš failed to 
strike a chord in the souls outside their respective national spaces and they preserved some significance only within their original cultural canons. This failure reveals a systemic shortcoming of not only Yugoslav, but also all other multicultural institutional arrangements of equal representation and recognition. They make promises which cannot be fulfilled: they can provide knowledge of the elements of other cultural traditions, but they cannot guarantee that these elements will be recognized as values, and productively accepted and assimilated within other national patrimonies. Here, the question of value is crucial: Kočo Racin may have failed to become a value in other national spaces, but Macedonian theater director Slobodan Unkovski, however, has not. Without ever having been a "representative" of Macedonian culture — who would have been taken into account for reasons elaborated by Yugoslav cultural policy-he in fact used to direct all over the former country, and he has enriched other Yugoslav national spaces by offering them his creativity, by raising the standards of theater directing, and thus contributing to their accumulation of cultural capital. The work of Danilo Kiš, recognized as a value and productively included in the patrimonies of all Yugoslav peoples, offers a similar example.

The common cultural space strengthened Yugoslav cultures by providing a wider audience, an enrichment of the various groups' cultural resources, and a shared space for dialogue and competition - free from the danger of suffocation or domination. And they all only benefited from it. If the period between 1960 and 1991, which, despite including at least fifteen years of economic austerity not conducive to cultural production, was nevertheless the richest era of cultural history for all Yugoslav national cultures, it is at least partially due to the existence of this supra-national cultural layer. Take any fifteen years from that period and compare it with the 
achievements of all ex-Yugoslav cultures from 1995 to 2010, and you will see what was lost with its disappearance.

It could be argued that the obvious provincialism and intellectual and creative poverty of all post-Yugoslav cultures must be explained by the wars, the transition from socialism to capitalism, and the predominant nationalistic disposition in all of them, in addition to international sanctions and isolation in the case of Serbia. This is certainly true. However, the wars and isolation were the direct outcomes of the dissolution of Yugoslavia, which also destroyed its supra-national cultural layer: without the dissolution there would have been no wars and isolation, and the transitional impoverishment would have been easier to bear. As for nationalism, it is at the same time the cause and an effect of the dissolution: it is not only perpetually maintained and stirred up by the successor states, but guaranteed to remain in place by the incoherent and ad hoc solutions which the "international community" has devised for identical problems in Croatia, Macedonia, Serbia, Kosovo, and Bosnia and Herzegovina. On the other hand, admitting that there must be a period of post-war recovery, and presuming that the successor nation states would take better care of all national affairs, including culture, than the supra-national Yugoslavia was able to - as was the promise of the nationalist leaders who worked on destroying it—we can proceed to compare the present state of affairs with the previous period of post-war recovery. As I am writing this chapter, it should be 1961 in Croatia and Bosnia and Herzegovina, or 1956 in Serbia and Macedonia. In spite of the incomparably greater level of death and destruction of the Second World War, in addition to the period of Stalinist repression which lasted until at least 1950, there was not only a whole new brilliant generation of artists, writers, and thinkers entering the Yugoslav cultural scene in the late 1950s, which would bring about the most fruitful period in all ex-Yugoslav cultures between 1960 and 
1990, but this fifteen-year long period had already produced a long list of exceptional achievements, resulting both from individual creativity and the state's concern for cultural development. Focusing only on Serbian culture, one could list Stevan Hristić's ballet “Ohridska legenda" and Ljubica Marić's cantata "Pesme prostora"; Ivo Andrić's novels Na Drini ćuprija, Travnička hronika, and Prokleta avlija, Dobrica Ćosić's Daleko je sunce and Koreni, Oskar Davičo’s Pesma, Radomir Konstantinović’s Daj nam danas, and Miodrag Bulatović’s Djavoli dolaze; Vasko Popa's collections of poems Kora and Nepočin polje, Miodrag Pavlović's 87 pesama, Jovan Hristić's Dnevnik o Ulisu, and Stevan Raičković's Pesme tišine and Balada o predvečerju; the exhibitions of Milan Konjović, Petar Lubarda, and Ivan Tabaković, or of the Zadar Group (Petar Omčikus, Bata Mihajlović, Mića Popović, and Vera Božičković) and of the December Group (Ćelić, Srbinović, and Protić). Despite wartime destruction, the National Library (1946) and the National Musem (1952) opened their doors to visitors fairly quicklywhile both institutions have been closed for a number of years in this second post-war period. The state established a number of new theaters: in Sombor, Subotica, Užice, Priština (1945), Kruševac, Vranje, Zaječar (1946), Kikinda (1950), the Beogradsko dramsko pozorište (1947), the Jugoslovensko dramsko pozorište (1948) and the Pozorište na Terazijama (1949), the "Boško Buha" Theater (1950) and Atelje 212 (1956) in Belgrade, and the Srpsko narodno pozorište in Novi Sad opened for opera (1947) and ballet (1950). A number of new museums were opened: the Muzej Saveza jevrejskih opština (1945), the Muzej grada Beograda (1945), the Galerija Matice srpske (1947), the Jugoslovenska kinoteka (1949), the Vukov i Dositejev muzej (1949), the Muzej pozorišne umetnosti (1950), the Muzej primenjene umetnosti (1950), the Muzej Nikole Tesle (1952), the Galerija Sava Šumanović in Šid (1952), the Galerija fresaka (1953), the Muzej prvog spskog ustanka (1954), and the Muzej srpske pravoslavne crkve (1954). The state 
organized the highly successful exhibition of Serbian medieval painting in Paris, and residents of Belgrade had an opportunity to see exhibitions dedicated to the works of Henry Moore, Pablo Picasso, Georges Braque, and Henri Matisse. NIN, the weekly which had a huge influence on Yugoslav culture, was founded in 1952, as well as the literary journals Književnost, Delo, and Savremenik. The film company "Avala film" was founded in 1946, the Academy for Theater in 1949, and the Sterijino pozorje festival in 1956.

Despite poverty and wartime destruction, culture was taken seriously in this period, and it showed serious results. Anyone familiar with the cultural scenes in the successor states has to admit that neither do the new nation states take culture seriously, nor has, thus far, a creative generation of the same caliber made an entrance. Despite all its shortcomings, despite periods of repression, ideological rigidness, and censorship, Yugoslavia was much more successful in managing its cultural affairs and creating conditions for cultural production than all of its successor states. ${ }^{11}$ And it created these conditions not only for the supra-national cultural layer which I am focusing on in this chapter, but for all individual cultures as well. It is curious that those, who in the late 1980s and early 1990s waxed lyrical about their respective nations'

${ }^{11}$ Snježana Kordić has recently contrasted Yugoslav language policy with those of its successor states: although three quarters of Yugoslavs spoke one language, no single language was official on a federal level. Official languages were declared only on the level of constituent republics and provinces, and very generously at that: Vojvodina had five (among them Slovak and Romanian, spoken by $0.5 \%$ of the population), and Kosovo four (Albanian, Turkish, Romani, and Serbo-Croatian). Newspapers, radio, and television studios used sixteen languages, fourteen were used as languages of education in schools, and nine at universities. See Snježana Kordić, Jezik i nacionalizam (Zagreb: Durieux, 2010). 
"thousand-year-long dream of statehood," failed to notice that Yugoslavia was an obstacle to the realization of this dream for only seventy years — and not a very significant one at that — and that Yugoslavia had prepared all the necessary cultural preconditions for the fulfilment of this dream. During the Yugoslav period, Slovenia established its first university and institute of higher education in Slovene, in addition to the hermetically-sealed linguistic space in which the media, publishing, and all levels of education were well protected from the penetration of SerboCroatian - in striking contrast to the relationship between Slovene and German throughout the nineteenth century. Macedonians also achieved the standardization of their language and all levels of education only in Yugoslavia; almost all of Macedonian culture falls within that period. Similarly, Albanians achieved the standardization of their northern dialect, accompanied by all levels of education in Albanian, along with a complete infrastructure for cultural development, such as publishing houses, theaters, media, the University, and the Institute for Albanology in Prish tina. ${ }^{12}$ Just the list of cultural and educational institutions founded in the second Yugoslavia demonstrates that nationalists, especially those from the smaller nations, should celebrate this period instead of cursing it. As some really have: for Aleš Debeljak, an early promoter of Slovene nationalism, Yugoslavism in 1986 was a "formula which suppresses all specific national characteristics under the same glass bell," the "triumph of unitarism over the autonomy and equal rights of Yugoslav peoples," and the "melting of all peoples into one supra-national organism." ${ }^{13}$ Yugoslavism was founded on typification and standardization, in which all

${ }^{12}$ Gilles Troude, Conflits identitaires dans la Yugoslavie de Tito 1960-1980 (Paris: Association Pierre Belon, 2007), 231-38.

${ }^{13}$ Aleš Debeljak, "Zastarelost jugoslovanstva" [The Obsoleteness of Yugoslavism], Nova revija 5, nos. 52-53 (1986): 1390-92. 
"individual national impulses, concepts, traditions, and cultures" disappear, claimed Debeljak; it was part of the conservative project of globalization, based on militant Aufklärung ideas, and as such, obsolete in postmodern times, which celebrate the "pulsation of national emotions and identifications." ${ }^{14}$ In 1994, however, the same author no longer saw Yugoslavia as an oppressive glass bell, but as a multicultural country in which "our linguistic, artistic, national, and religious differences converged in productive synthesis." ${ }^{15}$ It may just simply be a difference between one publication aimed at a Slovene readership, which in the mid-1980s liked to read about the "pulsation of national emotions," and another aimed at an international audience, which in the mid-1990s was horrified by the effect of these pulsations; in any event, Debeljak aptly, if belatedly, expressed the advantages the common Yugoslav culture had offered him: "The longing for a bigger market, a broader audience, a more numerous readership: all of these are legitimate feelings on the part of former Yugoslavs."16

These institutions have survived the dissolution of Yugoslavia, but the layer of common culture to which that state gave birth has been irreparably destroyed, without any substitute for it being offered. What Tim Judah recently termed the "Yugosphere" can hardly represent such a substitute, and can only be understood as a pale shadow of the vibrant and productive layer of

${ }^{14}$ Ibid., 1393-94.

${ }^{15}$ Aleš Debeljak, Twilight of the Idols: Recollections of a Lost Yugoslavia (New York: White Pine Press, 1994), 35.

${ }^{16}$ Ibid., 25. 
common culture in Yugoslavia. ${ }^{17}$ Within the "Yugosphere" the visit of a Slovene actor to Belgrade is an event marked by newspaper articles and television interviews. In the Yugoslav common cultural layer, however, in the late 1980s the Slovene actor Radko Polič flew from Ljubljana to Belgrade several times a month to act in Ljubiša Ristić's production of Cement in Atelje 212; neither Polič nor his audience found it unusual, let alone worth mentioning in newspapers.

On the other hand, the idea that the successor cultures, once and if they become members of the European Union, will find there a similar broader paradigm which will offer them a wider audience - an opportunity to appropriate others' patrimony without risking political supremacy and cultural dependency, and encounter other cultures in a spirit of dialogue and competition, but on more or less equal terms - is an idea that can be examined in the case of Slovenia, which is already an EU member. As for the wider audience, it is absolutely clear that the visibility of Slovene culture in the European Union is nowhere near that guaranteed to it under the Yugoslav arrangements. There is not a single program of systematic and continuous translation of Slovene literature, financed by a host country, such as those run by Narodna knjiga from Belgrade in the 1970s and 1980s. No other European Union country included France Prešern's or Ivan Cankar's works in school curricula, as had other Yugoslav republics. If you study German literature in Berlin or Spanish literature in Madrid, you do not need to take a compulsory course in Slovene literature, as was required of those who studied Croatian literature in Zagreb or Serbian literature

${ }^{17}$ Tim Judah, Yugoslavia is Dead: Long Live the Yugosphere, LSEE Papers Series, no. 1 (London: London School of Economics and Political Science, European Institute, Research on South Eastern Europe, 2009). 
in Belgrade. As for the Slovene language, nowadays it is protected within Slovenia as much as it was before the independence - a higher level of protection is difficult to conceive of - but outside of it, it is less visible than it was in Yugoslavia. The Yugoslav institutional arrangements for representation and recognition may have been imperfect, but the European Union still does not have anything even remotely similar. In the wider European context, such institutional arrangements seem impracticable, given the large numbers of member states and their relative inequality in strength, resources, and numbers. Nor has the demise of multiculturalist policies, which have been quietly abandoned in the United Kingdom, and loudly rejected in Germany, created an atmosphere conducive to thinking about institutionalizing any similar arrangements, which would at least provide knowledge of smaller European cultures, even if these cultures must rely on themselves for the value, productivity, and significance of their elements. The European common cultural layer in the making is formed solely according to a value criteria, as the Yugoslav one was, but it will necessarily put cultures poor in resources and numbers at a greater disadvantage, because the competition for an opportunity to speak and be heard by others will be much fiercer than it was in the dissolved country of twenty-million strong. This means that opportunities for encountering others in a spirit of dialogue and competition, for entering the European common cultural layer in the making, are reserved only for rare individuals who are able to earn it by their own merit: Slavoj Žižek is the only Slovene name that comes to mind in this context. Disregarding this precious exception, the position of Slovene culture within broader European culture is similar to that enjoyed by Croatian, Serbian, and Slovene cultures in the broader Austria-Hungarian one: they were "of it," they "belonged to it," and quietly sitting in the backbenches they were allowed to appropriate its cultural patrimony and to complain about their 
cultural dependency, but without the benefit of a wider audience and the opportunity to encounter other cultures in a spirit of dialogue and competition on more or less equal terms.

With the disappearance of the Yugoslav common cultural layer and the institutional arrangements which provided for the representation and recognition of national cultures in the dissolved country, former Yugoslavs have lost a lot, and gained nothing. Once this cultural layer was destroyed, what was left was only the national cultures - small, poor in resources, provincial, and unable to step out into the wider arena - but surprisingly satisfied with this state of affairs. 